\title{
TECHNOLOGY TO REDUCE ENERGY COSTS IN THE ELECTRIC STEEL MELTING SHOP
}

\author{
${ }^{1}$ FA Hoshimov, ${ }^{1}$ I U Rakhmonov*, ${ }^{1}$ N N Niyozov \\ ${ }^{1}$ Tashkent state technical university, Tashkent.
}

\begin{abstract}
The article proposes a technological scheme of energy consumption for enterprises of the textile industry using technical means. On the basis of experimental studies in the field of energy saving in industrial enterprises, in particular in the tequistine industry, the main criteria for optimizing the whole variety of tasks for energy saving and assessing the corresponding energy indicators of units and enterprises in general are being developed. In addition, methodological foundations of experimental research on energy saving at operating industrial enterprises are being developed, taking into account technological and operational factors affecting energy consumption levels.
\end{abstract}

\section{Introduction}

The task of rational use of electricity in electric steelmaking production can be considered not only as achieving the minimum level of energy consumption, but also as the task of optimal distribution of electricity between individual processes and workshops of the enterprise, by segments of the planned period and by types of products.

\section{Main part}

For an objective analysis of the efficiency of electricity consumption and making decisions on its management, it is necessary to have a differentiated system for assessing the efficiency of electricity use at the current time and a forecast for the planned period, i.e. you need to know what kind of return on energy consumption can be expected at a particular facility at different periods of time under different production conditions [1-4].

For various production redistributions, multifactor models of power consumption allow solving a number of urgent problems of increasing the efficiency of power consumption both at the level of individual units and workshops, and at the level of the enterprise as a whole.

The complexity of solving the problem of assessing the efficiency of electricity consumption is due to the fact that in practice the values of the objectively required electricity costs are unknown and the problem has to be solved on the basis of information characterizing the amount of actual energy consumption in specific production conditions, which, even for consumers of the same type, can differ very significantly. This is determined by a number of both technological and operating parameters of the process, which leads to a significant variation in the indicators of electrical use. Therefore, a higher level of power consumption at individual units and technological limits can be fully justified in view of the difficult objective conditions of production.

Therefore, comparison of the efficiency of electrical consumption is possible only under the same or similar production conditions. For the metallurgical industry, there is a number of homogeneous technological units and industries with a common technology and equipment of the same type, for which it is possible to assess not only the difference in the efficiency of energy consumption, but also to establish, due to what factors and by what amount there was a deviation from the average or advanced indicators of energy consumption ...

Attaching exceptional importance to finding reserves for saving fuel and energy reserves, in order to concentrate the efforts of scientists and specialists in solving specific problems in the implementation of energy-saving policies, the following technology is proposed to reduce energy consumption at enterprises [5-8].

The technology provides for the development of new methods and technical solutions to reduce energy costs and optimize the consumption of fuel, electric and thermal energy in the main processes of industrial production using technical means of accounting, control and management, as well as the development of experimental research methods on the existing equipment of industrial facilities and the compilation of mathematical models nacontrol parameters of power consumption modes, providing a minimum energy consumption.

The proposed energy saving technology provides for a study technological and operational factors affecting the reduction of the energy intensity of industrial products. The complex of studies includes the creation of a single information fund for specific sectors of the national economy, characterizing the technical, technological, organizational and economic aspects of the transformation, distribution and use of energy resources.

\footnotetext{
Corresponding author: ilider1987@yandex.com
} 
Estimation of the predicted value of reducing the "peak" power when using technical means of control:

a) assessment of the predicted value of the reduced power (theoretical forecast);

b) an estimate of the lead time of a 30-minute excess of the declared capacity during the maximum hours of the power system.

Reducing energy costs by introducing technological measures with the solution of subtasks:

a) optimization of technological parameters in electric power processes;

b) the same in electrothermal processes.

Reducing electricity losses in the power supply system, in machines and devices with the solution of subtasks: system;

b) the same in electrical machines and apparatus, electrothermal units;

c) optimization of the operating mode of devices by reactive power compensation.

Modernization and renewal of the fleet of machines and mechanisms with the purpose of reducing energy consumption by solving subtasks:

a) modernization of the existing fleet of machines and mechanisms;

b) replacement of machines, mechanisms, processes with less energy-intensive ones.

Implementation of organizational measures to reduce energy consumption with the solution of subtasks:

a) introduction of an automated accounting, control and management system energy consumption;

b) the same for the components of the technological process (compressed air, water, gas, steam, etc.);

c) organization of collection and storage of statistical information on the dynamics of changes in energy indicators;

d) development of methods of regulation and organization of control over their observance.

Thus, the whole range of research and implementation of energy saving measures is reduced to solving 8 tasks and 22 subtasks.

Decomposition scheme of the specific power consumption indicator

Given the presence of a significant number of interrelated energy saving measures, including electrical, a) reduction of electricity losses in the power supply

technological and many other factors of such a complex indicator as the energy intensity of products, the method of system analysis should be adopted as a method for analyzing research and calculation [9-12].

Naturally, the developed scenario should include all the above tasks, taking into account the specific features of the object under study.

The specified scenario should include two stages of work: The first stage - a set of studies to identify sources of savings in the operation of individual units.

The second stage - the same for workshops and enterprises.

Next, we take, as an objective function, the indicator of specific power consumption and, on its basis, we build a decomposition scheme for this indicator.

Considering that at the first stage of research, the issues of energy saving within the framework of single units should be resolved, the scope of work should cover almost all subtasks of the specified decomposition scheme in the following technological sequence:

a) characteristics of the unit, study of the design features of the unit;

- technological process and characteristics of the processed product;

- unit operation mode (continuous, intermittent, pauses, etc.);

b) characteristics of auxiliary machines and mechanisms and their mode of operation;

c) organization of operation of the electrical and technical part of the unit (lubrication, cleaning);

d) experimental research - active and reactive power, power consumption, energy consumption of products.

Optimality criterion for energy performance

At the first stage of solving the problems stipulated by the scheme of decomposition of the indicator of specific power consumption, it is necessary to justify the choice of such optimality criteria, which must correspond to the entire complex of many characteristic components of the objective function [13-17].

The global criterion for the optimality of the whole variety of events energy saving is the minimum of the energy component of the production cost.

However, this optimum can be reached through the optimization of all components of the entire complex of works.

Table 1.

\begin{tabular}{|c|c|c|c|c|c|c|}
\hline \multirow[t]{3}{*}{ № } & \multirow[t]{3}{*}{$\begin{array}{l}\text { Objective } \\
\text { function }\end{array}$} & \multirow[t]{3}{*}{ Indicative list of activities } & \multicolumn{4}{|c|}{ Optimality criterion } \\
\hline & & & \multicolumn{2}{|c|}{ Without capital costs } & \multicolumn{2}{|c|}{ With capital costs } \\
\hline & & & $\begin{array}{l}\text { without } \\
\text { performan } \\
\text { ce } \\
\text { degradatio } \\
\mathrm{n}\end{array}$ & $\begin{array}{l}\text { with a } \\
\text { decrease in } \\
\text { productivit } \\
y\end{array}$ & $\begin{array}{l}\text { without a } \\
\text { decrease in } \\
\text { productivity }\end{array}$ & $\begin{array}{l}\text { with a } \\
\text { decreas } \\
\text { e in } \\
\text { perfor } \\
\text { mance }\end{array}$ \\
\hline 1 & 2 & 3 & 4 & 5 & 6 & 7 \\
\hline 1 & $\begin{array}{l}\text { Electricity } \\
\text { losses (kWh / } \\
\text { year) }\end{array}$ & $\begin{array}{l}\text { 1) Voltage level normalization } \\
\text { 2) Increasing the efficiency of } \\
\text { the units } \\
\text { 3) improving the quality of PPR }\end{array}$ & $\begin{array}{l}\text { Minimum } \\
\text { losses } \mathrm{kWh} \\
\text { / year }\end{array}$ & & $\begin{array}{l}\text { Minimum } \\
\text { estimated } \\
\text { costs, sum / } \\
\text { year }\end{array}$ & \\
\hline
\end{tabular}




\begin{tabular}{|c|c|c|c|c|c|}
\hline & & $\begin{array}{l}\text { 4) improvement of current } \\
\text { operation } \\
\text { 5) reactive power compensation } \\
\text { 6) reduction of losses in the } \\
\text { electrical system } \\
\text { supplies }\end{array}$ & & & \\
\hline 2 & $\begin{array}{ll}\text { Energy } & \text { intensity } \\
\text { of } & \text { products } \\
(\mathrm{kWh} / & / \text { food } \\
\text { unit }) & \end{array}$ & $\begin{array}{l}\text { 1) reduction of energy losses (in } \\
\text { machines and mechanisms) } \\
\text { 2) reduction of product defects } \\
\text { 3) improving the quality of raw } \\
\text { materials } \\
\text { 4) increasing the coefficient of } \\
\text { extraction of a useful product } \\
\text { from raw materials } \\
\text { 5) improving the performance } \\
\text { of equipment } \\
\text { 6) increasing equipment } \\
\text { utilization } \\
\text { 7) reduction of equipment idle } \\
\text { 8) reduction of consumption of } \\
\text { components of the technological } \\
\text { process (compressed air, water, } \\
\text { steam, etc.) }\end{array}$ & $\begin{array}{l}\text { Minimum } \\
\text { losses kWh } \\
\text { / year }\end{array}$ & $\begin{array}{l}\text { Minimum } \\
\text { estimated } \\
\text { costs, sum / } \\
\text { year }\end{array}$ & \\
\hline 3 & $\begin{array}{l}\text { Power } \\
\text { consumption } \\
(\mathrm{kW})\end{array}$ & $\begin{array}{l}\text { 1) reduction of power losses } \\
\text { 2) compliance with the normative } \\
\text { parameters of raw materials and } \\
\text { semi-finished products } \\
\text { 3) ensuring the standard temperature } \\
\text { in metallurgy and metalworking } \\
\text { 4) maintaining the standard voltage } \\
\text { in electrothermal processes } \\
\text { 5) equipment speed regulation } \\
\text { 6) increasing equipment utilization }\end{array}$ & $\begin{array}{l}\text { Minimum } \\
\text { losses kWh } \\
\text { / year }\end{array}$ & $\begin{array}{l}\text { Minimum } \\
\text { estimated } \\
\text { costs, sum / } \\
\text { year }\end{array}$ & $\begin{array}{l}\text { Minim } \\
\text { um } \\
\text { estimat } \\
\text { ed } \\
\text { costs, } \\
\text { sum / } \\
\text { year }\end{array}$ \\
\hline 4 & $\begin{array}{l}\text { Declared power } \\
(\mathrm{kW})\end{array}$ & $\begin{array}{l}\text { 1) shift in operating time of the units } \\
\text { 2) shutdown of units for the } \\
\text { maximum period } \\
\text { 3) reducing the load of the units for } \\
\text { the period of maximum } \\
\text { 4) optimization of the time of load } \\
\text { drops and technological pauses } \\
\text { 5) the use of intermediate } \\
\text { warehouses and stocks of semi- } \\
\text { finished products for regulatory } \\
\text { purposes } \\
\text { 6) creation of backup equipment for } \\
\text { regulatory purposes }\end{array}$ & $\begin{array}{l}\text { The } \\
\text { minimum } \\
\text { declared } \\
\text { power } \\
(\mathrm{kW}) \text {. } \\
\text { timing } \\
\text { parameters }\end{array}$ & $\begin{array}{l}\text { Minimum } \\
\text { estimated } \\
\text { costs, sum / } \\
\text { year }\end{array}$ & $\begin{array}{l}\text { Minim } \\
\text { um } \\
\text { estimat } \\
\text { ed } \\
\text { costs, } \\
\text { sum / } \\
\text { year }\end{array}$ \\
\hline 5 & $\begin{array}{l}\text { Production cost } \\
\text { (sum of food } \\
\text { items) }\end{array}$ & Items 1 - 4 & \multicolumn{3}{|c|}{$\begin{array}{l}\text { The minimum energy component of the production } \\
\text { cost }\end{array}$} \\
\hline
\end{tabular}

Table 1 shows the criteria for the optimality of measures in the main areas of work:

- reduction of electricity losses;

- reducing the energy consumption of products;

- reduction of power consumption of units, workshops and enterprises;

- reduction of the "peak" power of the power system.

Analysis of the indicators in Table 1 shows that the criteria for the optimality of measures carried out without capital expenditures and without reducing productivity are: the minimum specific and absolute consumption of electricity and the minimum declared capacity, in the presence of capital costs, the minimum estimated costs in monetary terms (sum / year), including in itself energy and cash costs with a given payback period.

\section{Conclusion}

1. A technological scheme of energy consumption for enterprises of the textile industry with the use of technical means is given. The scheme provides for a step-by-step 
study of power consumption modes with the identification of reserves for saving electricity and optimizing energy performance using automated metering, control and management systems.

2. Criteria for optimization of the whole variety of tasks for energy saving and assessment of the corresponding energy indicators of units and enterprises in general have been developed.

3. Methodological foundations for experimental research on energy saving at operating industrial enterprises have been developed, taking into account technological and operational factors affecting the levels of energy consumption.

4. The most effective measures to reduce the power consumption of units and algorithms for choosing the most advantageous mode, as well as the participation of the unit in the process of regulating the electrical load of the enterprise, have been developed.

\section{References}

1. Rakhmonov, I.U., Niyozov, N.N. (2019) Optimization setting of steel-smelting industry in the issue of alloy steels E3S Web Conf 139 doi:10.1051/e3sconf/201913901077

2. Rakhmonov, I. U., Tovbaev, A.N., Nematov, L.A., Alibekova,T.Sh. (2020) Development of forecasted values of specific norms for the issues of produced products in industrial enterprises Journal of Physics: Conference Series 1515 doi:10.1088/1742$6596 / 1515 / 2 / 022050$

3. Rakhmonov, I.U., Reymov, K.M., Najimova, A.M., Uzakov, B.T., Seytmuratov, B.T. (2019) Analysis and calculation of optimum parameters of electric arc furnace Journal of Physics: Conference Series 1399 doi:10.1088/1742-6596/1399/5/055048

4. Hoshimov, F.A., Bakhadirov, I.I., Erejepov, M., Djumamuratov, B. (2019) Development of method for normalizing electricity consumption E3S Web Conf 139 doi:10.1051/e3sconf/201913901074

5. Karimov R.Ch., Bobojanov M.K., Rasulov A.N., Usmanov E.G. E3S Web of Conferences, 139, 01039, (2019), doi.org/10.1051/e3sconf/201913901039;

6. Karimov R.Ch., Shamsiyev K., and others. IOP Conf. Series: Materials Science and Engineering, 883(1), 012142, (2020). doi:10.1088/1757-899X/883/1/012142;

7. E.G.Usmanov, A.N.Rasulov, M.K.Bobojanov, R.Ch.Karimov. E3S Web of Conferences 139, 01079 (2019), doi.org/10.1051/e3sconf/201913901079;

8. Karimov R.Ch., Shamsiyeva N. and others. IOP Conf. Series: Materials Science and Engineering, 883(1), 012120, (2020). doi:10.1088/1757-899X/883/1/012120

9. G.R.Rafikova, M.R.Ruzinazarov, S.K.Makhmutkhonov. E3S Web of Conferences, 139, 01075,

(2019), https://doi.org/10.1051/e3sconf/201913901075

10. Khakimov,H.T., Shayumova,Z.M., Kurbanbaeva,Z.K ., Khusanov,B.M. Development of optimal modes and mathematical models of energy performance of electric steelmaking production//E3S Web of Conferences, 2019, 139, 01076

11. Khushnud Sapaev and Shukhrat Umarov. Two approaches for automating analysis of electromagnetic processes in non-linear circuits with valves. Web of Conferences https://doi.org/10.1051/e3sconf/20191390 E 3S 139 (2019) 101085 RSES 20198

12. Allayev, K.R., Fedorenko, G.M.,Postnikov, V.I.,Ostapchuk, L.B. Asynchronous generators as power system's natural dampers. 43rd International Conference on Large High Voltage Electric Systems 2010, CIGRE 20102010, 9p43rd International Conference on Large High Voltage Electric Systems 2010, CIGRE 2010; Paris; France; 22 August 2010.

13.Fazylov, Kh.F.,Allaev, K.R. Analysis of the operation of an electrical system during simultaneous operation of synchronous and asynchronous generators. Power engineering New York Volume 18, Issue 3, 1980, Pages 81-88.

14.Fazylov, Kh.F.,Allaev, K.R. Asynchronous turbogenerators with stator excitation and the prospects for their utilization. Power engineering New York Volume 23, Issue 2, 1985, Pages 7-13.

15. Fazylov, Kh.F.,Allaev, K.R. Calculation and experimental analysis of conditions of electrical power systems containing induction generators Power Engineering New York Volume 27, Issue 6, 1989, Pages 27-34.

16. Allaev K., Makhmudov T. Research of small oscillations of electrical power systems using the technology of embedding systems. Electrical Engineering, 2020; Issue 1: 309-319. DOI 10.1007/s00202-019-00876-9

17. Allaev K., Makhmudov T. Prospects of diversification and ensuring energy safety of Uzbekistan. E3S Web Conf., Volume 139, 2019, Rudenko International Conference "Methodological problems in reliability study of large energy systems" (RSES 2019).https://doi.org/10.1051/e3sconf/201913901002 